\title{
A Rare Variant of Middle Turbinate Extending to the Nasal Vestibule Misinterpreted as Nasal Cavity Tumor
}

\author{
Ji-Hwan Park, MD, Keun-Ik Yi, MD, Kyu-Sup Cho, MD, PhD and Sung-Dong Kim, MD \\ Department of Otorhinolaryngology and Biomedical Research Institute, \\ Pusan National University Hospital, Busan, Korea
}

\begin{abstract}
- ABSTRACT -
Concha bullosa $(\mathrm{CB})$ is the pneumatization of the middle turbinate. Although $\mathrm{CB}$ alone is usually asymptomatic, CB may be so extensive that it can come into intimate contact with large areas of the nasal septum and the lateral wall of the middle meatus, predisposing the patient to nasal obstruction and recurrent headaches. Herein, we report an uncommon case of huge $\mathrm{CB}$ extending to the nasal vestibule and occluding the whole nasal cavity. (J Clinical Otolaryngol 2019;30:97-99)
\end{abstract}

KEY WORDS : Congenital abnormalities $\cdot$ Turbinates $\cdot$ Nasal obstruction $\cdot$ Headache.

\section{Introduction}

Pneumatization of the middle turbinate is called concha bullosa (CB) regardless of the amount and location of the pneumatization. ${ }^{1)} \mathrm{CB}$ is the most frequently encountered anatomical variation of the lateral nasal wall, ${ }^{2)}$ and is usually asymptomatic. However, an extensively pneumatized middle turbinate may constitute a space-occupying mass, and thus, it may cause nasal obstruction and impaired nasal breathing. ${ }^{3)} \mathrm{A}$ huge $\mathrm{CB}$ extending forward into the nostril is extremely rare, and have not been reported in the literature, to the best of our knowledge. Herein we describe this rare clinical presentation of a huge $\mathrm{CB}$ extending to the nasal vestibule that almost completely obstructed the nasal cavity.

논문접수일 : 2019년 3월 6일 논문수정일 : 2019년 4월 1일 심사완료일 : 2019년 4월 29일 교신저자 : 김성동, 49241 부산광역시 서구 구덕로 179 부산대학교병원 이비인후과

전화 : (051) 240-7824·전송 : (051) 246-8668

E-mail:applekims@hanmail.net

\section{Case Report}

A 33-year-old woman presented with progressive nasal obstruction of the both sides and recurrent headache for 20 years. The endoscopic examination showed an expansive and large mass with normal mucosa that filled the whole left nasal cavity and a nasal septum deviation to the right (Fig. 1). A computed tomography (CT) showed extensively pneumatized left middle turbinate extending to the nasal vestibule. The bulging head of the middle turbinate completely filled the space between the septum and the lateral nasal wall (Fig. 2). The patient underwent a transnasal endoscopic surgery following septoplasty under general anesthesia. After a vertical incision on the anterior wall of the $\mathrm{CB}$, the resection of the lateral wall of middle turbinate was performed. The postoperative course was uneventful, and nasal obstruction and headache ceased. Endoscopic examinations performed 1 month postoperatively demonstrated that the nasal airway was adequate (Fig. 3). 


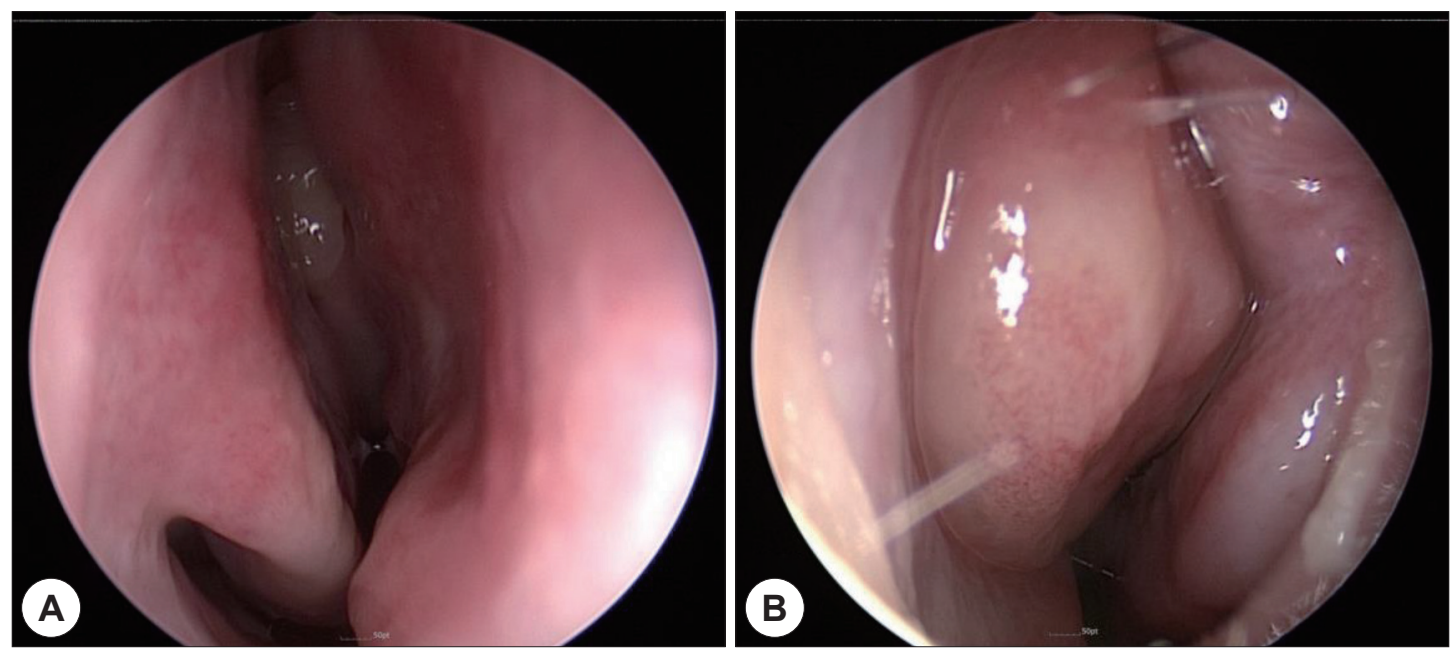

Fig. 1. Preoperative endoscopic findings. A : Nasal septum is deviated to the right side. B : Nasal endoscopy shows an expansive, large mass with normal mucosa filled the majority of left nasal cavity.

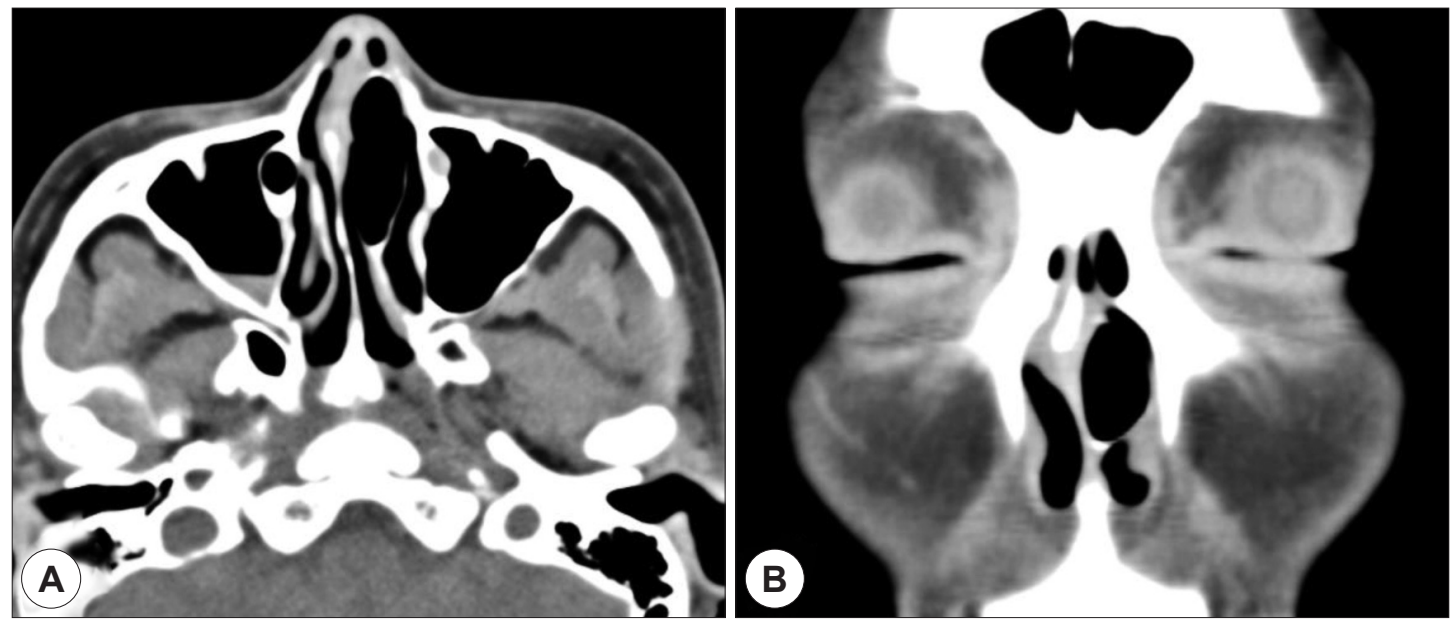

Fig. 2. Preoperative paranasal computed tomographic (CT) images. Axial (A) and coronal (B) CT images show extensively pneumatized left middle turbinate extending to the nasal vestibule. A deviation of the septum to the right is noted.

\section{Discussion}

Although the pneumatization mechanism of the middle turbinate has not yet been fully understood, the pneumatization of the middle turbinate may originate from the middle meatus, frontal recess, ethmoid infundibulum, and agger nasi cells. ${ }^{3)}$ The air continues to enter the concha, which cannot be drained, thus the pressure inside the concha increases and the concha continues its anterior and lateral expansion in the nasal cavity. If the pneumatization is extensive, a huge CB may cause unpleasant symptoms such as nasal obstruction. In our case, the left middle turbinate had grown extensively to the nasal vestibule, and it caused complete left nasal obstruction and headache.

The severity of symptoms due to $\mathrm{CB}$ is closely associated with the degree of pneumatization. CB may be asymptomatic, but may present symptoms such as 


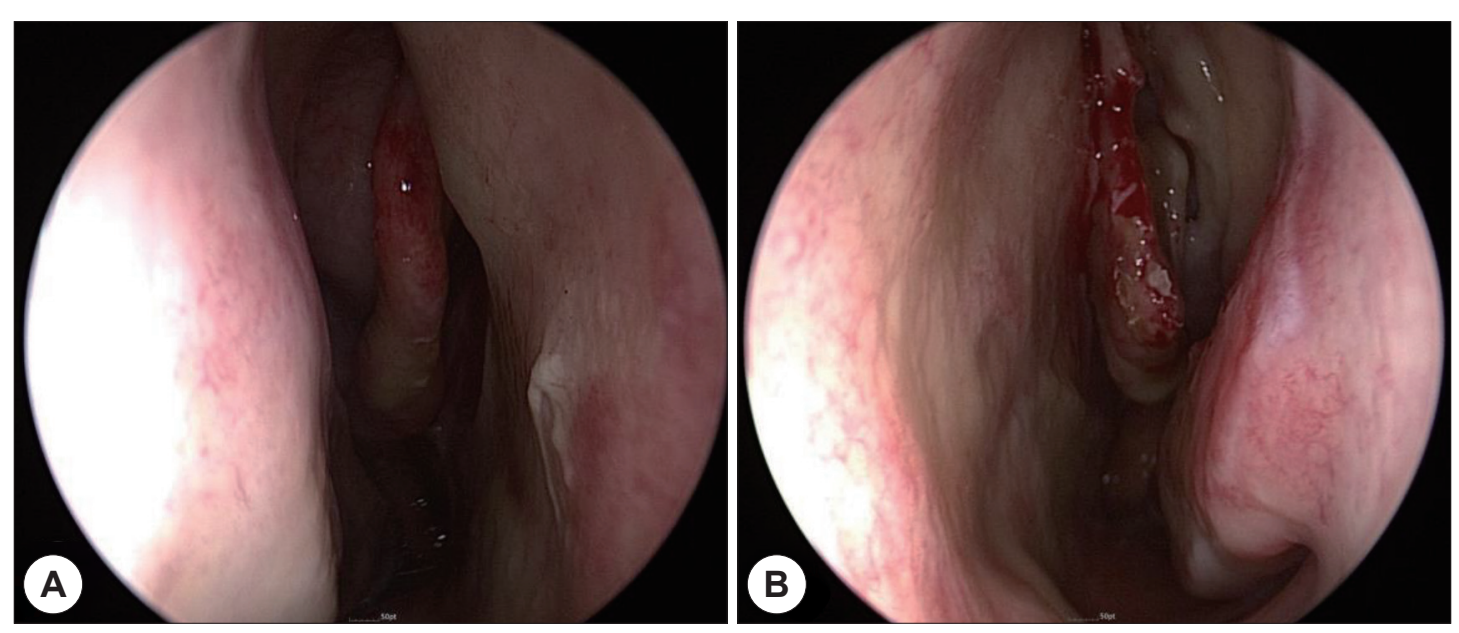

Fig. 3. Postoperative endoscopic findings. A : A deviation of the nasal septum is corrected. B : Nasal endoscopy performed at 1 month postoperatively demonstrates well preserved medial lamella and resected lateral lamella of middle turbinate.

nasal obstruction, headache, and hyposmia by means of entire filling of the nasal cavity. Such a huge CB may impair ventilation and drainage of the osteomeatal complex and thus lead to sinusitis. Although septal deviation does not give rise to the formation of $\mathrm{CB}$, it augments the pneumatization of the middle turbinate, depending on the degree of the angle of deviation angle. ${ }^{4)}$ In this case, there was a severe deviation of the septum to the right side, and this encouraged the development of a huge left $\mathrm{CB}$.

The diagnosis of $\mathrm{CB}$ consists of a nasal endoscopic examination and a CT scan. The CT scan aids the preoperative scheduling, but also alerts the surgeon to possible anatomic variations of the middle turbinate. When a mass produces unilateral nasal obstruction, it must be distinguished from a variety of benign lesions such as nasal polyp and from tumorous conditions including inverted papilloma, chondrosarcoma, osteosarcoma, and fibroosseous lesion. ${ }^{5}$

The treatment of symptomatic CB is the partial endoscopic resection of the middle turbinate. We performed lateral wall resection of the CB with septoplasty to relieve nasal obstruction. It is important to avoid excessive manipulation of the medial wall of the concha bullosa because the medial lamella is attached to the skull base.

\section{Conclusion}

Although the anatomical anomalies in this patient are very rare and mimicked a nasal cavity mass, both endoscopic and CT findings supported the diagnosis of a huge $\mathrm{CB}$ extending to the nasal vestibule. Therefore, these findings should be considered by otolaryngologists, and careful examination of the nasal cavity should be carried out to determine the existence of this rare anomaly.

This work was supported by the year 2019 clinical research grant from Pusan National University Hospital.

\section{REFERENCES}

1) Ozcan KM, Selcuk A, Ozcan I, Akdogan O, Dere H. Anatomical variations of nasal turbinates. J Craniofac Surg 2008; 19(6):1678-82.

2) Okuyucu S, Akoglu E, Dagli AS. Concha bullosa pyocele. Eur Arch Otorhinolaryngol 2008;265(3):373-5.

3) Braun H, Stammberger H. Pneumatization of turbinates. Laryngoscope 2003;113(4):668-72.

4) Uygur K, Tuz M, Dogru H. The correlation between septal deviation and concha bullosa. Otolaryngol Head Neck Surg 2003;129(1):33-6.

5) Toledano A, Herraiz C, Mate A, Plaza G, Aparicio JM, De Los Santos G, et al. Mucocele of the middle turbinate: a case report. Otolaryngol Head Neck Surg 2002;126(4):442-4. 